\title{
Quality Management Practices and Quality Performance: A Thematic Analysis of Indonesia's Health Service Provider
}

\author{
AMANDA ACINTYA* \\ Universitas Gadjah Mada
}

\begin{abstract}
Preceding literature indicates that service organizations are lagging behind manufacturing firms in terms of the effective deployment of Total Quality Management (TQM) practices to achieve operational and strategic goals. Given the paucity of TQM researches in service and the Non-for-Profit sector, the objective of this study is to shed some light on the current TQM practices of and their relation to the service company's quality performance. Thematic analysis is used to develop the constructs of $Q M$ practices under two strands: Infrastructure or "Soft" Quality Management (QM) Practices and Core or "Hard" QM Practices. Each theme will be further broken down into its subthemes, which have a positive correlation with quality performance based on past researches. The paper derives its primary insights from in-depth interviews and focuses groups with healthcare service employees. It analyses inductively the employee's perspectives of QM practices implemented in the organization. This research depicts the organization's enthusiasm in implementing TQM practices and confirms the role of Core TQM as a mediating variable of Infrastructure TQM and Quality Performance qualitatively, as suggested by past literature. This study also illustrates a considerably small theoretical-practical gap of QM practices on the supplier relationship and responsibility for quality performance. More importantly, this study underscores the differences in TQM implementation practices due to some industry-specific factors.
\end{abstract}

Keywords: Quality Performance, Total Quality Management, Infrastructure TQM, Core TQM, Thematic Analysis

\begin{abstract}
Abstrak: Literatur terdahulu menunjukkan bahwa organisasi jasa belum banyak diteliti dalam dalam hal penerapan praktik manajemen kualitas total (TQM) secara efektif yang bertujuan untuk mencapai tujuan operasional dan strategis. Terbatasnya penelitian TQM di bidang jasa dan nirlaba menjadikan penelitian ini kesempatan untuk memberikan gambaran praktik TQM yang diimplementasikan dan bagaimana praktik tersebut berhubungan dengan kinerja kualitas. Analisis tematik digunakan untuk mengembangkan konstruk penelitian dari praktik Manajemen Kualitas. TQM dibagi menjadi dua tema yaitu Praktik Manajemen Kualitas Infrastruktur dan Praktik Manajemen Kualitas Inti. Setiap tema selanjutnya akan dipecah menjadi subtema yang terbukti memiliki korelasi dengan kinerja kualitas berdasarkan penelitian sebelumnya. Penelitian ini bersifat kualitatif dengan metode pengumpulan data melalui wawancara dan focus group kepada karyawan sebuah organisasi penyedia layanan kesehatan.
\end{abstract}

*Corresponding author: amandaacintya@ugm.ac.id 
Data selanjutnya dianalisis secara induktif. Hasil penelitian kualitatif ini menggambarkan antusiasme sebuah organisasi jasa dalam menerapkan praktik TQM dan mengkonfirmasi penelitian terdahulu terkait peranan Praktik Manajemen Kualitas Inti sebagai variable mediasi. Studi ini juga menggambarkan adanya kesenjangan antara teoritis-praktis dalam hal pemilihan pemasok dan pembagian tanggung jawab atas kualitas yang disebabkan oleh faktor industri spesifik.

Kata kunci: Kinerja Kualitas, Total Quality Management, Manajemen Kulitas Infrastruktur, Manajemen Kulitas Inti, Analisis Tematik

\section{Introduction}

In today's world, both public and private organizations are on an equal footing to meet the demand for quality. Customers demand companies be able to produce highquality products and services in the increasingly competitive market conditions. Companies can use several key management practices to maximize performance, one of which is the Total Quality Management (TQM) (Mowen, Hansen, and Heiger, 2016). In the sphere of competitive pressures, Talib and Rahman (2012) considered that TQM is a strategy that companies need to survive through principles and practices aimed at achieving customer needs and expectations. In a similar vein, Yapa (2012) suggests that the implementation of TQM is not only needed to generate profits but also in order to survive in an increasingly competitive environment.

Based on their function and objective, QM practices can be classified into Infrastructure QM practices (also known as "Soft" QM) and Core QM practices ("Hard" $\mathrm{QM})$. The former category is QM practices that contain both human and cultural aspects. In contrast, the latter relates to the techniques and methods of the company, including the use of data and quality information, product design process, as well as process management. Past researchers found that both practices have impacts on quality performance, customer satisfaction, and organization performance (Rahman and Bullock, 2005; Fotopoulos and Psomas, 2009).

Despite the importance of quality performance, past literature indicated that little is known on the implementation of $\mathrm{QM}$ techniques in service organizations, and it is still far less than in the manufacturing industry (Brah et al., 2000). Although many companies in various service industries, such as health care and insurance, have begun 
to pay attention to TQM (Hasan and Kerr, 2003), there is not much of extensive research on the area. The first attempt to analyze the implication of TQM in a service industry was carried out in the American context by Saraph et al. (1989), whose outcomes provide eight critical areas of quality management as a framework to build theories and models that relate QM to the quality environment and quality performance. Then, Bouranta et al. (2019) carried forward a literature study from 1989 to 2017 that concludes five main elements underlie TQM practices in the service industry. Bouranta et al. (2019) state that differences of opinion among researchers regarding the main elements underlying TQM in the service industry can be caused by differences in definitions, methodological approaches, company size, and business environment of each of these studies.

Several studies have been undertaken to identify which elements of QM practice are contributing positively to the $\mathrm{QM}$ performance, but to date, no consensus is reached amongst researchers (Flynn et al., 1994; Ahire et al., 1996). Bouranta et al. (2017) concluded that four of the five elements of TQM affect the financial performance of hospitality in Greece. However, there are several studies on small and medium-sized businesses that conclude that the implementation of TQM does not significantly influence financial performance (Demirbag, 2006; Kober et al., 2012). The inconclusive result is not only present in the research on causal relationships between $\mathrm{QM}$ practices but also in the contribution of each construct of QM practice to organizational performance.

Given the paucity of research on the use of QM practices by service organizations and their distinctiveness relative to larger companies, this case study seeks to contribute to the various findings in the QM literature about how different QM practices, specifically, Infrastructure QM practices and Core QM practices, affect quality performance in a service organization. Due to the plausible specificity of a case study, our findings should be taken as a light to understand the QM practices in the industry. The readers should attempt to generalize these findings to other organizations.

The research objectives of this study are: (1) to determine the extent to which QM practices are being implemented and (2) to explore the underlying reasons and rationale 
why specific QM practices are not used or at least not theoretically effective in a service organization. To address these objectives, we conducted in-depth field interviews at Gadjah Mada Health Centre (GMC), a university's health service provider in Yogyakarta, Indonesia. Respondents were asked on the extent to which GMC was implementing Infrastructure and Core QM practices that the researcher has formerly categorized using thematic analysis.

The paper is arranged as follows. First, I draw upon many QM practices based on past researchers in order to develop a comprehensive framework. Within this section, I explore the theme and subthemes of Infrastructure and Core QM practices. Then, the research methodology is presented, followed by the findings and analysis. Finally, a conclusion is attended.

\section{Theoretical Framework}

\subsection{Quality Management}

There has been a considerable increase in research interest over the past 30 years on QM practices implemented in organizations. Research in this area ranges from academic studies to a more celebratory agenda. Malcolm Baldridge National Quality Award (MBNQA), which is based on the Deming Prize in Japan, is highly regarded in the American business context. US Government Accounting Office (GAO) tests the influence of TQM's development strategy on the performance of the 20 highest-ranked American companies, as indicated by MBNQA 1988/1989. The study finds that there is a strong positive relationship between the use of TQM practices and company performance as measured by quality, productivity, customer satisfaction, employee relations, and profitability.

However, it is essential to note that if we look more detailed to what constructs the Infrastructure and Core QM practices and its implication to quality performance, the findings differ amongst researches (Sousa and Voss, 2002). Several studies have reported that only Infrastructure QM practices such as executive commitment, employee empowerment, and consumer focus contribute to quality improvement while Core QM practices such as benchmarking, information, and analysis, use of advanced technology 
is not influential (Powell, 1995; Samson and Terziovski, 1999). On the contrary, some studies have found a positive relationship between Core QM practices and quality performance (Rahman and Bullock, 2005). Other studies have also reported that Infrastructure QM practices such as executive roles, employee relations, engagement employees, employee selection, and development do not have a significant effect on quality performance. Another finding is drawn from Flynn et al. (1995) that there is an existence of hierarchy in QM practices. They found that for Infrastructure QM practices to have a positive correlation with organizational performance, Core QM practice should be substantially in place. In this regard, Core QM practices laid as a solid foundation to enhance the strong and positive correlation of Infrastructure QM practices and quality performance (Ho et al., 2001).

The non-uniformity of past researches may result from the following three reasons - first, the differences in the categorization of Infrastructure QM practices and Core QM practices amongst them. For example, Dow et al. (1999) consider the relationship to suppliers as one of the practices of Core, while Rahman and Bullock (2005) treat it as a construct of Infrastructure. The second reason is the difference in performance levels measured in each research (Kaynak, 2003). Some studies like Powell (1995) measure performance financial, other researchers such as Dow et al. (1999) focusing on quality performance, while some researchers like Samson and Terziovski (1999) measures the quality, productivity, and employee morale performance. Finally, differences can occur because of the inequalities of the analytical method used to investigate the relationship between QM practices and company performance (Kaynak, 2003; Sousa and Voss, 2002). Some studies conclude that the practice of Infrastructure can support the performance of the company in the absence of Core QM practice using correlation analysis (e.g., Dow et al., 1999; Powell, 1995) while others use multiple regression analysis (e.g., Samson and Terziovski, 1999).

While it is beyond the scope of this paper to find the root cause for differences, the findings from the researches mentioned above on QM practices indicate that there is no consensus on what constructs Infrastructure and Core QM and how does that correlate to quality performance. 


\subsection{Infrastructure $Q M$ Practices}

Infrastructure QM Practices, also known as Soft QM Practices, emphasize the human and cultural aspects. These practices focus on management commitment and leadership, supplier relationship, customer relationship, as well as human resource management (Flynn et al., 1995). Common constructs of Infrastructure QM practices, e.g., Flynn et al. (1995) and Zu (2008), are presented below.

The first construct is the management leadership style. According to Alolayyan et al. (2011), top management is critical to the success of TQM implementation in improving organization performance. Top management carries the role to shape the beliefs and trust of the employes within the organization structure. In a total quality setting, Goestch and Davis (1997) found that a participative leadership style is believed to be the most appropriate style. As opposed to a traditional approach, a participative style empowers employees to contribute. To consider the employee input, implement the input-based decision in the right way, work with employees to improve weak ideas, and reward for improvements are TQM characters that make it distinct from the traditional approach.

The second construct is the relationship with the customers. The main objective of TQM is customer satisfaction, which is measured by the company's ability to meet and exceed customer expectations (Hauser and Clausing, 1988). According to Harrington, et al. (2012) in Psomas and Jaca (2016), customer satisfaction is guaranteed either through the high quality or competitive price. In that way, satisfied customers will continue to improve the frequency and size of their purchase. Unlike the traditional management practice that usually measures performance based on results (profit or loss), a company with a customer focus applies quality leadership. This concept aims to meet and exceed customer expectations so that the company can provide value for the long term.

It is widely believed that customers need changes. Pressures such as technology, market competition, international conflict, and social problems drive changes in customer needs or priorities. Therefore, companies must use effective mechanisms to facilitate communication and support the concept of customer focus. Hence, 
information related to customers needs to be collected through several methods like survey, focus group, and complaint management.

The third construct is the relationship with the suppliers. Suppliers can contribute to the company's quality performance in various ways. The supplier contract is one of the most common tools to bind the customer in the long term. With the contract, the buying company is expecting some advantages such as lower production costs, increased accountability, loyalty suppliers, and reduction in end product variability. On the other side, suppliers also benefit from achieving economies of scale.

The key to maximizing the contribution of suppliers lies in the ability of the organization to choose suppliers in small quantities and establish long term commitment with them. More importantly, for a service organization, supplier selection should be based on quality considerations, not cost. Besterfield (1999), in his book Total Quality Management, defines two forms of cooperation between companies and suppliers in general.

One way to manage supplier is through sourcing. Sourcing can take many forms depending on the number of suppliers the organization has the contract with. Companies that adhere to sole sourcing are forced to use only one supplier. Such condition is caused by various factors such as patents, technical specifications, remote location, competitive advantage on product differentiation, etc. In a slightly different context, single sourcing is a situation where the company chooses one supplier despite other options available. Multiple sourcing occurs when companies use two or more suppliers in which the portion of each supplier is usually determined based on price, quality, and delivery process. The underlying reason for this form of cooperation is that in most cases, competition produces better quality, lower cost, and service is superior.

The last Infrastructure QM Practice construct is workforce management. Fulford and Enz (1995) find that employee perceptions of empowerment affect employee loyalty and job satisfaction. Schlesinger and Heskett (1991) also find that employee perceptions of quality have a positive relationship with the ability to provide services and job satisfaction. From the two studies above, it can be deduced that employee empowerment brings about greater commitment, better performance, and higher job 
satisfaction. Thus, organizations need to manage their workforce to strengthen work attitudes through training to cater to continuous employee growth and development. Goetsch and Davis (1994) define training as a series of activities that are organized in a systematic and aims to strengthen the knowledge, skills, and motivation of employees about the scope of his work. This applies not only to the operational workers but also for the managers to be given equal training so they can exercise leadership in total quality settings.

\subsection{Core QM Practices}

Core QM Practices, sometimes identified as Hard QM Practices (Rahman, 2005), emphasize on statistical methodology. A study of Zu (2008) and Flynn et al. (1995) in the manufacturing sector adopts two constructs of Core QM.

The first construct is process management, which is a systematic practice that combines human resource management with technical aspects to regulate and improve the quality of processes in producing goods and services (Gutiérrez et al., 2010). It also relates to how a company designs and introduces its products or services, integrating between the production and delivery process, as well as managing supplier performance (Evans and Lindsay, 2002). Integration is carried out with the help of using TQM tools such as statistical process control (SPC), check sheets, scatter diagrams, cause-andeffect diagrams, Pareto charts, flowcharts, and histograms (Heizer et al., 2017). Under this concept, it is believed that a company is consists of some interconnected processes. So, to improve company performance, it starts with an improvement in the process. Moreover, Kumar et al. (2008) found that companies with excellent process management have a significant influence on customer satisfaction. However, it is still debatable whether this QM practice is an integral component of the historical and thematic initiatives (Smart et al., 2004).

The second construct relates to data and quality information. All companies that operate the TQM system will pay attention to all their production activities so that the process of collecting and analyzing the data related to the activity is needed. Companies can use existing data to detect problems, identify root causes, decide corrective steps, and initiate monitoring programs. Access to data is not only needed by the management 
line, but also by lower-line employees. The superiority of data is one of the critical factors in maintaining a competitive position because it can accelerate the company to respond to customer requests and improve quality levels.

\section{Research Method}

\subsection{Research Object}

Qualitative descriptive research aims to understand the characteristics of phenomena or problems that exist obtained by researchers from the subject of individual, organizational, industrial, or other perspectives. A qualitative case study method is adopted for this study because the primary research question investigates a 'how' question given the implementation of Infrastructure and Core QM practices within each company is unique.

The author chose Gadjah Mada Medical Center as a research object due to the dearth of research on the implementation of TQM and its relation to performance quality in service companies, especially in healthcare providers. Although it is not the intention of any qualitative study to generalize, it does not eliminate the possible resemblances of QM practices being implemented in similarly-characterized organizations.

Founded in 2000, Gadjah Mada Medical Center (GMC) is a Non-for Profit healthcare provider for students and employees of Universitas Gadjah Mada (UGM) in Yogyakarta, Indonesia. GMC's vision is to become an institutional health service that integrates high-quality and efficient health services. Its mission is to provide comprehensive health services, including health promotion and disease prevention and treatment to all participants. Almost all GMC operational processes are carried out by PT Askes in the first year. At the same time, the GMC management is responsible for administering health insurance and overseeing the service costs health. In September 2003, GMC was officially independent and fully responsible for the operationalization of a primary healthcare provider for UGM members. Since then, GMC has continued to improve its performance by taking over all the roles of PT Askes. 


\subsection{Data Collection}

In-depth interviews were conducted with 4 GMC employees using purposive sampling. Purposive or purposeful sampling is defined by Frey et al. (2000, p. 132) as "non-randomly selected based on a particular characteristic". Interviewees were selected based on the managerial position and job responsibilities (Table 1). A cross-section of interviewees is attended to allow responses from lower-level employees to top-level managers in different functions. Also, this research conducts document analysis and observation to ensure validity.

Table 1.

Interviewee Profile

\begin{tabular}{|c|c|c|c|}
\hline Interviewee Code & Position & $\begin{array}{c}\text { Managerial } \\
\text { Level }\end{array}$ & Gender \\
\hline EMP A & Director & Senior & Female \\
\hline EMP B & $\begin{array}{c}\text { Vice Director }- \\
\text { Medical }\end{array}$ & Senior & Female \\
\hline EMP C & $\begin{array}{c}\text { Pharmacy Support } \\
\text { Staff }\end{array}$ & Junior & Male \\
\hline EMP D & $\begin{array}{c}\text { Pharmacy Support } \\
\text { Staff }\end{array}$ & Junior & Female \\
\hline
\end{tabular}

Following contact by permission letter for research, the interviews were conducted in Indonesian with an average time of 60 minutes for individual interviews and 120 minutes for FGD. As the original interviews were conducted in Indonesian, these were converted to English.

\subsection{Data Analysis}

Qualitative data were analyzed using thematic analysis, defined as a method for identifying, explain, analyze, and report on themes and patterns in the data (Braun and Clarke, 2006). The basic analytic strategy used in the thematic analysis is coding; that is the process of checking the text to search for recurring themes, topics, or relationships and marking parts that are similar to codes or labels to categorize them in the theoretical development effort. 
To identify themes, this research adopts a theoretical or deductive or top-down approach of thematic analysis. A theoretical thematic analysis would tend to be driven by the researcher's theoretical or analytic interest in the area that entails the efforts of data coding to fit into a pre-existing coding frame or the researcher's analytic preconceptions. Researchers can use research questions, interview questions, or categories, which is based on theory as the formation of the initial theme for the coding process (Mills, 2010). This form of thematic analysis tends to provide less a rich description of the data overall, and more detailed analysis of some aspect of the data.

Figure 1

Proposed model of Infrastructure QM Practice and Quality Performance. So urce: Rahman and Bullock (2002), Lakhal et al., (2005), Zu (2008)

\begin{tabular}{|c|c|c|}
\hline $\begin{array}{l}\text { Theme 1: Supplier } \\
\text { Relationship } \\
\text { 1. Suppliers are evaluated based } \\
\text { on quality, price, and } \\
\text { shipping process } \\
\text { 2. Work closely to improve } \\
\text { efficiency }\end{array}$ & & $\begin{array}{l}\text { The me 2: Customer } \\
\text { Relationship } \\
\text { 1. Periodic communication } \\
\text { 1. Customers provide } \\
\text { feedback } \\
\text { 2. Customer satisfaction } \\
\text { evaluation }\end{array}$ \\
\hline & $\begin{array}{l}\text { QM Practices } \\
\text { and Quality }\end{array}$ & \\
\hline $\begin{array}{l}\text { The me 4: Workforce } \\
\text { Manage ment }\end{array}$ & Performance & $\begin{array}{l}\text { The me 3: Management } \\
\text { Leadership } \\
\text { 1. Top management is } \\
\text { responsible for quality } \\
\text { performance } \\
\text { 2. The management } \\
\text { approach is personal } \\
\text { 3. Top management is } \\
\text { evaluated based on quality } \\
\text { performance } \\
\text { 4. The head of the division } \\
\text { participates in efforts to } \\
\text { improve quality } \\
\text { 5. Imposing the goal of } \\
\text { improving quality to } \\
\text { employees }\end{array}$ \\
\hline
\end{tabular}


Figure 2

Proposed model of Core QM Practices and Quality Performance.

Source: Saraph et al., (1989), Samson and Terziovski (1999), Zu (2008)

The me 1: Process Management

1. The company has a patent method for measuring service performance

2. The company has standardized and documented operating procedures

\section{Theme 2: Quality Data and} Information

1. Quality data is available to managers and employees

2. Quality data is always updated and reliable

3. Use of quality data to evaluate employee performance

Given the deductive nature of this thematic research, the interview questions are developed within the framework of six themes of Infrastructure and Core QM, as proposed in Figure 1 and 2 above. To have a complete understanding of the research object, both open-ended and close-ended questions are attended. A copy of the interview guide can be found in Appendix 1.

\section{Results and Discussion}

\subsection{Infrastructure Quality Practices and Quality Performance}

Based on the thematic research model between the Infrastructure QM and the quality performance mentioned above, this analysis will consist of 4 themes and its pertinent sub-themes.

\section{Theme 1: Relationship with Supplier}

The process of supplying medicine at GMC is carried out every three months based on a monthly forecast. The medicine forecast is mainly dependent on the historical consumption data of the previous month. GMC also considers several factors, such as 
disease outbreaks, academic activities holidays, and seasons in determining the size of orders. GMC has a monthly budget of IDR 50.000.000 for the purchase of drugs, and usually, at the end of the month, the ending inventory value is around IDR 10.000.000. This inventory level is considered normal, considering the GMC as a health care provider should not be running out of stock. If a drug is needed urgently, the GMC will contact the three-drug suppliers. Pharmacy with the lowest bid price that GMC will later choose.

With regards to supplier evaluation, the majority of our respondents confirmed that the evaluation is majorly depending on the supplier quotation:

The selection of drug suppliers in GMC is made by direct appointment or through procurement based on the Rector Decree. The direct appointment is made for the two internal pharmacies responsible for providing the whole generic drugs, while for other drugs, it is done through procurement. Amongst those participants, a pharmacy that offers the lowest quotation and excellent delivery performance [based on historical data] will be chosen. All this time, GMC never really face a significant decline in supplier performance that might hamper their service operations (EMP D)

All suppliers are located within the city of Yogyakarta to increase the efficiency of time and cost. The cooperation between GMC and these pharmacies began in 2005, in which the provision of drugs was held previously by PT Askes. A total of three pharmacies is currently serving GMC. Two of them are internal university pharmacies, whereas the other one is an independent external pharmacy.

The result of this study is contrary to the research of $\mathrm{Zu}$ (2008) and Manoochehri (1985), who argue that supplier performance evaluation should be based on quality, price, and shipping process instead of price. It is interesting to note, however, that Rahman and Bullock (2005) perceive supplier relation as a context-dependent variable and suggest that it is likely to be more relevant in the manufacturing sector than service organizations. 


\section{Theme 2: Relationship with Customers}

Regarding customer relations, GMC conducts an annual survey and Focus Group Discussion regularly to assess customer satisfaction and to generate feedback.

We conduct regular customer satisfaction surveys every year. The survey was conducted to monitor our quality performance and to locate our rooms for improvement. The survey is distributed directly to the visiting patients, analyzed and later, brought up to the evaluation meeting with top management (EMP B)

GMC conducted a survey annually by adopting the concept of SERVQUAL (Service Quality) that is commonly used to assess quality performance in service companies. The questionnaire uses a 5-scales Likert method to assess two aspects. First, the service aspect includes all customer-facing employees, including doctors, nursing, registration officers, pharmacy officers, claim officers, laboratory officers, etc. Whereas secondly, the service support aspect includes the condition of the rooms and overall customer experience. Also, there are three open questions about overall customer satisfaction, expectations, and customer suggestions. In theory, the survey is typically conducted twice, that is before and after the patients receive treatments. However, GMC only performs after service delivery for efficiency reasons.

As for customer complaint-handling management, patients may submit a complaint and provide feedback through customer satisfaction surveys, FGD, or complaint box. The GMC complaint analysis begins with the Customer Service department to capture all the incoming complaints. The further complaint will be reported to the management and discussed in regular meetings to determine the needed corrective actions.

We are still developing a standardized system to gather customer feedback. Currently, things are done manually and involving paperwork [..]. In responding (to complaints), the Customer Service Division initiates a meeting with relevant stakeholders, and together, we try to develop solutions. The majority of the complaints were on the customer's waiting time. We realized that our staff was taking dual responsibility of a lecturer and a doctor, so sometimes they showed up behind schedule. We could not do much, but we tried to reschedule this doctor- 
lecturer for an evening shift (while allocating the full-time doctor in the morning shift). We are still trying to monitor if this solution works. (EMP A)

Although the efforts to manage complaints are identified, the approach is somewhat arbitrary and lack of a reliable handling system. Also, during the interviews, no respondents were mentioning any follow up actions to the customers whether their complaints have been adequately addressed.

Theme 3: Management Leadership

In GMC, the responsibility for quality performance is shared by all employees rather than solely at the top management level in contrast to the findings by Flynn (1995) and $\mathrm{Zu}$ (2008). The quality maintenance function is done in stages by all GMC employees. They are responsible for the effort following their respective authorities and responsibilities.

Top management is responsible for monitoring and controlling the overall business functions, whereas middle management focuses on daily operations. There is no distinct segregation of responsibilities for quality performance due to the relatively small size of this organization. We expect each employee to contribute to the overall organization performance within the respective role and responsibility (EMP A)

With regards to top-level management evaluations, each division is evaluated against targets and KPIs. The evaluation result is not reported separately, but it is embedded in one of the monthly coordination meetings attended by all GMC employees.

As a medical manager, I am responsible for overseeing the overall medical service provision and general affairs [...]. My performance is considered satisfactory, as indicated by a minimum number of patient complaints and drug availability [...]. Annual performance assessment is an exercise of both subjective evaluation and objective (historical) data. (EMP B)

Another subtheme is a personalized management approach, as seen in $\mathrm{Zu}$ (2008). Aligned with Goestch and Davis (1997), GMC management uses a contingency or situational approach that combines personal and formal approaches. A small 
organization with a flat organization structure like GMC might not get the most out of a strict formal system. Instead, a participative and personal approach empowers the organization member to give inputs for the decision making process. As a result, every decision is an output of collective efforts.

\section{Theme 4: Workforce Management}

The infrastructure QM practices establish a learning and cooperative organizational environment. For the service industry, workforce management is at the heart of the business process to deliver high-quality service. To ensure that, all GMC employees must attend an internship program for two to three months before being appointed as a permanent employee. Employees are also provided with on-the-job training under the direct supervision of a line manager to ensure high-quality deliverables. Interns or trainees will be offered a full-time position should they satisfy the quality requirement.

Table 2

Meeting Mechanism in GMC

\begin{tabular}{|c|c|c|c|}
\hline $\begin{array}{l}\text { Workforce } \\
\text { Management } \\
\text { Mechanism }\end{array}$ & Activity & Frequency & Key Stakeholder \\
\hline Operational Meeting & $\begin{array}{l}\text { To discuss business as } \\
\text { usual both at the strategic } \\
\text { and operational end }\end{array}$ & Every month & All employees \\
\hline $\begin{array}{l}\text { Top Management } \\
\text { Meeting }\end{array}$ & $\begin{array}{l}\text { To discuss strategic issues } \\
\text { that need managerial } \\
\text { discretion as well as to } \\
\text { monitor performance } \\
\text { (individual/organization) }\end{array}$ & Incidental & Top Management \\
\hline Medical Meeting & $\begin{array}{l}\text { Address issues within } \\
\text { internal coordination and } \\
\text { patients handling, schedule } \\
\text { working shifts, review } \\
\text { drug formulary }\end{array}$ & $\begin{array}{l}\text { Every two } \\
\text { weeks }\end{array}$ & $\begin{array}{l}\text { Top Management } \\
\text { Medical Division } \\
\text { Customer Service } \\
\text { Division }\end{array}$ \\
\hline Finance Meeting & $\begin{array}{l}\text { To review budget } \\
\text { realization, technical } \\
\text { payment issues, prepare } \\
\text { financial statements, etc. }\end{array}$ & Incidental & Finance Division \\
\hline
\end{tabular}

In regards to employee empowerment, GMC employees are involved in coordination meetings to determine policy and to seek input to improve quality 
performance. Small-scale coordination meetings are held regularly and carried out functionally. Details on the meeting schedules in GMC are summarized in Table 2.

With regards to communication style, respondents would define it as "informal" and "open" (EMP A, EMP B, EMP C, EMP D). The relatively small organization size of GMC is characterized by the relatively low bureaucratic system and informal communication. Agreed by the respondents, there is no significant barrier of communication from superior to subordinates and vice versa.

Increasing interaction also emerged due to the routine meetings and on-the-job training, allowing them to exchange information and work together to find possible solutions. In a few instances, it is common for a new employee to find difficulties in their daily work. To get help, direct interaction or meeting served as a medium in which employees "feel free" to share the contextual challenges (EMP C, EMP D).

\subsection{Core Quality Practices and Quality Performance}

\section{Theme 1: Process Management}

It is of the utmost importance that an organization achieves high-quality performance. Hence, organizations should regularly assess their performance so that when a nonconformance exists, corrective action should be undertaken on time. In order to gain effective process management, an organization should define clear performance indicators and performance assessment.

GMC assesses their quality performance in providing medical services using two measures, namely finance and service satisfaction. Service satisfaction indicators are obtained based on customer survey results. Financial performance has a heavier weight because this performance is used as the basis for providing performance incentives to all employees if GMC cost control is good for the year. The incentive is given at the end of each fiscal year, with a maximum amount of one month's salary.

Process management ensures that a company's business processes are welldesigned, implemented, and up-to-date. To achieve process conformity, GMC has Standard Operating Procedures (SOP) that are developed in stages and are continuously refined following the performance improvements made. A review of the GMC SOP is 
conducted every two years under a rather piecemeal approach in which each business process owner is responsible for safeguarding and making the necessary update of the process. For example, the SOP regarding filing a claim is held by the finance department, and the medical department holds the SOP related to health services.

\section{Theme 2: Quality Data and Information}

GMC has several data related to quality performance, e.g., the results of customer satisfaction surveys, customer satisfaction index, customer complaint database, Medical Service Standard (Standar Pelayanan Medis), drug formulary, and SOPs. GMC provides quality data in soft copy that is administered centrally by the General Administration Department. This is by the theory in "Introduction to Quality" by Goestch and Davis (1997), where computer-based data storage facilitates the search and accelerate response to customers. To ensure data is up-to-date and reliable, GMC conducts a regular review of the Medical Service Standard every four to five years. In contrast, a customer survey is conducted annually, and drug formularies every two to three years.

GMC uses customer satisfaction survey results in the employee evaluation process and 360-degree performance evaluation approach. The approach involves the assessment of three parties, among other colleagues, superiors, and subordinates. In addition to customer satisfaction survey results, Standard Medical Service is used to control the quality of GMC services. In contrast, the drug formulary is used to test the standard drug used by GMC.

It is interesting to note, however, that during the interview, our respondents implied that quality data and information did not directly contribute positively to quality performance. Instead, they perceive this core QM variable as support to infrastructure QM, implying its function as a mediator. In the few instances where the respondents were asked how would the availability of quality information helped them to maintain quality performance, the respondents would explain the mechanism by referring back to the infrastructure QM and how it would contribute to quality.

You know, [customer] survey is our primary quality data in which all management actions, be it preventive and corrective, lied upon. The data is a source to improve 
our service to customers as well as to evaluate the supplier performance [...] Our training curriculum is a mixture of the as-is condition as depicted by the (quality) data and to-be targets. So, if we find redflags, for example, based on the patient survey, we revise our standards or training material accordingly. (EMP A)

This finding advocate past research by Ho et al. (2001) that took Infrastructure QM and Core QM as two integrated variables in which Core QM mediated the impact of Infrastructure QM on quality performance.

\section{Conclusion, Implication, and Limitation}

This study aims to find out how is the implementation of Infrastructure and Core QM practices to improve quality performance in the service sector, as suggested by past quantitative studies. Based on the findings and qualitative analysis, it can be concluded that the majority of Infrastructure and Core QM practices at GMC are following the theoretical frameworks. Some caveats from this research found to lie in two subthemes. First, supplier evaluation criteria rely primarily on the quotation price instead of quality. Second, the responsibility for quality performance that is distributed across organization structure rather than holding solely on the top management. This study also reveals that the core QM practices mostly transmitted infrastructure QM practices such as training and management leadership (e.g., quality data and reporting), imitating a mediating variable.

One limitation of this study is that it has not considered the relationship between practices of sub-themes within the same theme. Future research is expected to be able to discuss in more detail and integrated that Quality Management should be implemented as an integrated approach of all types of practices (Flynn et al., 1995; Kaynak, 2003; Yeung et al., 2005). The existence of a relationship between one practice and another practice advises companies to implement $\mathrm{QM}$ practices to obtain maximu $\mathrm{m}$ outcomes effectively.

While it is not the intention of this study to qualitatively prove any causality between QM practices and quality performance, our case study suggests that the organization indeed found benefits from implementing QM practices. The positivist or empiricist 
researchers hold that qualitative methods are limited to suggest causal hypotheses or provide supporting data for "causal" quantitative research (e.g., Shavelson and Towne 2002). To provide a more holistic view, it is suggested for future research to extend this study from a quantitative approach.

\section{Reference}

Ahire, S.L., Golhar, D.Y., and Waller, M.A. 1996. Development and Validation of TQM Implementation Constructs, Decision Sciences 27 (1): 23-56.

Alolayyan, M.N.F., Ali, K.A.M., Idris, F. and Ibrehem, A.S. 2011. Advance mathematical model to study and analyse the effects of total quality management (TQM) and operational flexibility on hospital performance. Total Quality Management \& Business Excellence 22(12): 1371-1393. https://doi.org/10.1080/14783363.2011.625183

Besterfield, D. H., Besterfield-Michna, C., Besterfield, G.H., and Besterfield-Sacre, M. 1999. Total Quality Management, 2nd ed. New Jersey: Prentice-Hall, Inc.

Bouranta, N., Psomas, E.L., and Pantouvakis, A. 2017. Identifying the Critical Determinants of TQM and Their Impact on Company Performance: Evidence from The Hotel Industry of Greece. The TQM Journal 29 (1): 147-166. https://doi.org/10.1108/TQM-11-20150142 .

Bouranta, N., Psomas, E.L., Suarez-Barraza, M.F., and Jaca, C. 2019. The Key Factors of Total Quality Management in the Service Sector: A Cross-Cultural Study. Benchmarking: An International Journal 26 (3): 893-921. https://doi.org/10.1108/BIJ-09-2017-0240.

Boyatzis, R. E. 1998. Transforming qualitative information: Thematic analysis and code development. Thousand Oaks, CA, US: Sage Publications, Inc.

Brah, S.A., Wong, J.L. and Rao, B.M. 2000. TQM and business performance in the service sector: a Singapore study, International Journal Operations and Production Management 20 (11): 1293-1312.

Braun, V. and Clarke, V. 2006. Using thematic analysis in psychology, Qualitative Research in Psychology 3 (2): 77-101

Demirbarg, M., Tatoglu, E., Tekinkus, M., and Zaim, S. 2006. An Analysis of The Relationship between TQM Implementation and Organizational Performance: Evidence from Turkish SMEs. Journal of Manufacturing Technology Management 17 (6): 829-847. DOI: 10.1108/17410380610678828.

Dow, D., Samson, D. and Ford, S. 1999. Exploding the myth: Do all quality management practices contribute to superior quality performance? Production and Operations Management 8: 1-27

Evans, J.R., and Lindsay, W.M. 2002. The Management and Control of Quality, 5th ed. Ohio: South-Western 
Flynn, B.B., Schroeder, R.G., and Sakakibara, S. 1995. The Impact of Quality Management Practices on Performance and Competitive Advantage. Decision Sciences 26 (5): 660691

Fotopoulos, C.B., Psomas, E.L. 2009. The impact of "soft" and "hard" TQM elements on quality management results, International Journal of Quality \& Reliability Management 26 (2): $150-163$

Frey, L.R., Botan, C.H. and Kreps, G.L. 2000. Investigating Communication: An Introduction to Research Methods, 2nd ed., Allyn and Bacon, Boston, MA.

Fulford, M. D., and Enz, C. A. 1995. Human resources as a strategic partner in multiunitrestaurants. Cornell Hotel and Restaurant Administration Quarterly 36 (3): 24-29

Goetsch, David L. and Davis, Stanley B. 1997. Introduction to Total Quality: Quality Management for Production, Processing, and Services, 2nd ed. New Jersey: PrenticeHall, Inc.

Gutiérrez, L. J., Torres, I. T., and Molina, V. B. 2010. Quality Management Initiatives in Europe: An Empirical Analysis According to Their Structural Elements. Total Quality Management 21(6): 577-601. DOI: 10.1080/14783363.2010.483064.

Hasan, M. and Kerr, R. 2003. TQM and organizational performance in service organizations. The TQM Magazine 15 (4): 286-91

Hauser, J. R. and Clausing, Don. 1988. The House of Quality. Harvard Business Review. Retrieved July 10, 2002 from https://hbr.org/1988/05/the-house-of-quality

Harrington, H.J., Voehl, f. and Wiggin, H. 2012. Applying TQM to The Construction Industry. The TQM Journal 24 (4): 352-362 in Psomas, E.L. and Jaca, C. 2016. The Impact of Total Quality Management on Service Company Performance: Evidence from Spain. The International Journal of Quality \& Reliability Management

Heizer, J., Render, B. and Munson, C. 2017. Operation Management: Sustainability and Supply Chain Management. 12th ed. Edinburgh Gate: Pearson Education.

Ho, D.C.K., Duffy, V.G. and Shih, H.M. (2001), “Total quality management: an empirical test for mediation effect", International Journal of Production Research, Vol. 39 No. 3, pp. $529-48$.

Kaplan, R. S. 2001. Strategic Performance Measurement and Management in Nonprofit Organizations. Nonprofit Management and Leadership, 11: 353-370

Kaynak, H. 2003. The relationship between total quality management practices and their effects on firm performance, Journal of operations management 21 (4): 405-435

Kober, R., Subraamanniam, T., and Watson, J. 2012. The Impact of TQM Adoption on SME Financial Performance. Accounting and Finance 52 (2): 421-438. DOI: 10.1111/j.1467629X.2011.00402.x

Lakhal, L., Pasin, F., and Limam, M. 2005. Quality management practices and their impact on performance, International Journal of Quality and Reliability Management 23 (6): 62546

Manoochehri, G. H. 1985. Improving productivity with the just-in-time system, Journal of Systems Management 36: 23-26 
Maxwell, J. A. 2004. Using Qualitative Methods for Causal Explanation, Field Methods 16 (3): 243-64

Miles, M. B., \& Huberman, A. M. 1984. Qualitative data analysis. London: Sage.

Mills, A. J., Durepos, G., \& Wiebe, E. 2010. Encyclopedia of case study research (Vols. 1-0). Thousand Oaks, CA: SAGE Publications, Inc.

Mowen, M. M., Hansen, D.R., \& Heitger, D.L. 2016. Cornerstones of Managerial Accounting. $6^{\text {th }}$ edition. Boston: Cengage Learning.

Mueller, R.A. 1992. Implementing TQM in Health Care Requires Adaptation and Innovation, Quality Progress 25 (4): 57-9

Powell, T.C. 1995. Total quality management as a competitive advantage: a review and empirical study, Strategic Management Journal 16: 15-37

Prajogo, Daniel I. and Sohal, Amrik S. 2003. The relationship between TQM practices, quality performance, and innovation performance: An empirical examination, International Journal of Quality \& Reliability Management 20 (8): 901-918

Rahman, S. and Bullock, P. 2005. Soft TQM, Hard TQM, and Organisational Performance relationship: an empirical investigation, Omega 33: 73-83

Roulston, K. 2001. Data analysis and 'theorizing as ideology.' Qualitative Research 1(3): 279302

Saraph, J.V., Benson, G.P., and Schroeder, R.G. 1989. An instrument for measuring the critical factors of quality management, Decision Sciences 20: 810-29

Samson, D. A. and Terziovski, Mile. 1999. The relationship between total quality management and operational performance, Journal of Operations Management 17: 393-409

Schlesinger, Leonard and L. Heskett, James. 1991. The Service-Driven Company. Harvard business review 69: 71-81

Smart, P.A., Maull, R.S., Childe, S.J. and Radnor, Z.J. 2004. Capitalising on thematic initiatives: a framework for process-based change in SMEs, Production Planning \& Control 15 (1): 2-12.

Sohal, A. S. and Terziovski, Mile. 2000. TQM in Australian manufacturing: factors critical to success, International Journal of Quality \& Reliability Management 17 (2): 158-168

Sousa, R. and Voss, C. 2002. Quality management: universal or context dependent? Production and Operation Management. Special Issue on Quality Management.

Talib, F. and Rahman, Z. 2012. Total Quality Management Practices in Manufacturing and Service Industries: A Comparative Study. International Journal of Advanced Operations Management 4 (3): 155-176. DOI: 10.1504/IJAOM.2012.047634.

V. Kumar, D. De Grosbois, F. Choisne, U. Kumar. 2008. Performance measurement by TQM adopters, The TQM Journal 20 (3): 209 - 222

V. Kumar, P.A. Smart, H. Maddern, R.S. Maull. 2008. Alternative perspectives on service quality and customer satisfaction: the role of BPM, International Journal of Service Industry Management 19 (2): 176 - 187 
Yapa, Saman. 2012. Total Quality Management in Sri Lankan Service Organizations. The TQM Journal 24 (6): 505-517. DOI: 10.1108/17542731211270070.

$\mathrm{Zu}$, Xingxing. 2008. Infrastructure and core quality management practices: how do they affect quality, International Journal of Quality and Reliability Management 26 (2): 129-4 
The Indonesian Journal of Accounting Research - Sept, Vol. 22, No.3, 2019

intentionally blank 